\title{
ANALYSIS OF THE PREVALENCE OF INJURIES AND ASSOCIATED FACTORS IN BRAZILIAN CLIMBERS
}

\section{ANÁLISEDA PREVALÊNCIA DE LESÕES EFATORES ASSOCIADOS EM ESCALADORES BRASILEIROS}

ANÁLISIS DE LA PREVALENCIA DELESIONES Y FACTORES ASOCIADOS EN ESCALADORES BRASILEÑOS

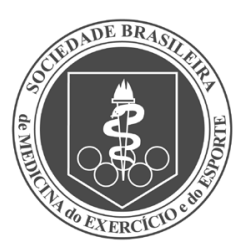

Original Article Artigo Original Artículo Original
Ana Flávia Câmara Figueiredo’ (Physiotherapist)

Luiz Filipe Cerqueira Barbosa² (Physiotherapist)

Kimberly Moreira Pereira da Silva ${ }^{3}$ (Physiotherapist)

Gleidson Mendes Rebouças ${ }^{4}$ (Physical Education Professional)

1. Centro Universitário do Rio Grande do Norte, Natal, RN, Brazil. 2. Universidade Potiguar, Natal, RN, Brazil.

3. Universidade Federal do Rio Grande do Norte, Natal, RN, Brazil. 4. Universidade do Estado do Rio Grande do Norte, Mossoró, RN, Brazil.

\section{Correspondence:}

Ana Flávia Câmara Figueiredo Rua Adail Pamplona de Menezes, 91 Parnamirim/RN, Brazil. 59151680. flacfigueiredo@gmail.com

\begin{abstract}
Introduction: Many Brazilians became climbing enthusiasts in the $20^{\text {th }}$ century, and the activity was recently included as an Olympic sport at the Tokyo 2020 Olympic Games. With the increase in the number of climbers seeking to beat personal and/or competitive records, the number of injuries has also increased. Objectives: To verify the prevalence of injuries in Brazilian climbers, as well as their association with sociodemographic characteristics and sport performance. Methods: A cross-sectional, descriptive and analytic observational study was conducted from March 2018 to May 2018 with the application of a virtual questionnaire for 266 Brazilian climbers. The statistical analysis was performed subsequently. Results: The prevalence of injuries in Brazilian climbers was $71.8 \%$. The main characteristics of the injuries that merited special attention were musculotendinous site (50.8\%), sport climbing (22.0\%), upper limb (50.3\%) and mechanism of abrupt movement (20.4\%). The most popular treatment was medical in combination with physiotherapy (34.5\%), and time off was generally more than 30 days $(50.3 \%)$. There was a significant association $(p<0.05)$ of the injuries with age, gender, region of the country, $B M I$, level of education and involvement in other sports, as well as athletic and recreational category, climbing time, basic course certificate, warming up, monthly rock climbing and weekly indoor climbing frequency, and the climbing grade. Conclusion: Due to the increase in the popularity of the sport and the high prevalence of climbers with a history of injuries, multiprofessional follow-up is needed to procure risk reduction programs and to enhance climbers' awareness of the factors associated with these injuries. Level of Evidence III; Study of nonconsecutive patients, without consistently applied "gold" reference standard.
\end{abstract}

Keywords: Mountaineering; Athletes injuries; Physiotherapy; Sports medicine.

\section{RESUMO}

Introdução: No século 20, a escalada passou a ganhar muitos adeptos brasileiros e, recentemente, foi incluída como esporte olímpico nos Jogos Olímpicos Tóquio 2020. Com o aumento no número de praticantes que buscam superações pessoais elou competitivas, tem-se aumentado também o número de lesões. Objetivo: Verificar a prevalência de lesões em escaladores brasileiros, bem como sua associação com as características sociodemográficas e desempenho esportivo. Métodos: Estudo observacional descritivo-analítico do tipo transversal, com aplicação de questionário virtual para 266 escaladores brasileiros, realizado de março de 2018 a maio de 2018. Posteriormente, foi realizada a análise estatística. Resultados: A prevalência de lesões nos escaladores brasileiros foi de 71,8\%. Dentre as principais características das lesões, destacaram-se as musculotendinosas (50,8\%), a modalidade escalada esportiva (22,0\%), o membro superior (50,3\%) e o mecanismo de movimento brusco (20,4\%). O tratamento mais procurado foi o médico associado ao fisioterapêutico $(34,5 \%)$, e o tempo de afastamento em geral foi de mais de 30 dias (50,3\%). Verificou-se associação significativa $(p<0,05)$ das lesões com idade, sexo, região do país, índice de massa corporal, nivel de escolaridade e prática de outros esportes, bem como categoria atleta e recreativo, tempo de escalada, certificado de curso básico, realização de aquecimento, frequência mensal da escalada em rocha e semanal da escalada indoor, e dos graus de dificuldade escalados. Conclusão: Como aumento da popularidade do esporte e a alta prevalência de escaladores com histórico de lesões, faz-se necessário - acompanhamento multiprofissional, em busca de programas de redução de riscos e maior conscientização dos escaladores quanto aos fatores associados a essas lesões. Nível de Evidência III; Estudo de pacientes não consecutivos; sem padrão de referência "ouro" aplicado uniformemente.

Descritores: Montanhismo; Traumatismos em atletas; Fisioterapia; Medicina esportiva.

\section{RESUMEN}

Introducción: En el siglo XX la escalada comenzó a ganar muchos adeptos brasileños y recientemente fue incluida como deporte olímpico en los Juegos Olímpicos de Tokio 2020. Con el aumento en el número de practicantes, que buscan superaciones personales y/o competitivas, ha aumentado también el número de lesiones. Objetivo: Verificar la prevalencia de lesiones en escaladores brasileños, así como su asociación con las características sociodemográficas y el desempeño deportivo. Métodos: Se realizó un estudio observacional descriptivo-analítico del tipo transversal, con aplicación de cuestionario virtual para 266 escaladores brasileños, de marzo de 2018 a mayo de 2018. Posteriormente se realizó el análisis estadístico. Resultados: La prevalencia de lesiones en los escaladores brasileños fue del 71,8\%. Entre las principales características de las lesiones se destacaron las músculo-tendinosas (50,8\%), la modalidad escalada deportiva (22,0\%), el miembro superior (50,3\%) y el mecanismo de movimiento brusco $(20,4 \%)$. El tratamiento más 
buscado fue el médico asociado al fisioterapéutico $(34,5 \%)$ y el tiempo de alejamiento de la práctica fue de más de 30 días (50,3\%). Se verificó una asociación significativa $(p<0,05)$ de las lesiones con la edad, sexo, región del país, índice de masa corporal (IMC), nivel de escolaridad y práctica de otros deportes, así como categoría atleta y recreativa, tiempo de escalada, certificado de curso básico, realización de calentamiento, frecuencia mensual de la escalada en roca y semanal de la escalada indoor, y de los grados de dificultad escalados. Conclusión: Con el aumento de la popularidad del deportey la alta prevalencia de escaladores con historial de lesiones, se hace necesario un acompañamiento multiprofesional en busca de programas de reducción de riesgos y mayor concientización de los escaladores en cuanto a los factores asociados a estas lesiones. Nivel de evidencia III; Estudio de pacientes no consecutivos, sin patrón de referencia "oro" aplicado uniformemente.

Descriptores: Montañismo; Traumatismos en atletas; Fisioterapia; Medicina deportiva.

\section{INTRODUCTION}

Climbing is a historical practice, where there are records of ascensions since the seventh century by the monk Em No Chokaku in Japan.' Considered challenging at personal, interpersonal, cognitive and physical levels, it can be practiced on rock or artificial walls, with different degrees of amplitude and difficulty. ${ }^{2}$

The sport climbing is a modality with routes that have distances of approximately 10 to 30 meters in height, where the climber connects the rope, which is fastened in its safety chair, in the fixed protections of the rock, in order to chain the track, meaning climbing from start to finish without falling, with the degree of difficulty ranging from 1 to $11 \mathrm{~b}$, according to the classification adopted in Brazil, demanding sports technique. The traditional Brazilian climbing differs by its long distance routes, with several fixed protections, which are usually more distant, making the falls more dangerous and demanding a good physical fitness. The bouldering is practiced without the use of ropes in small blocks of rocks of up to 6 meters, needing only the climbing shoe, magnesium carbonate to remove the sweat of the hands, and some mattresses in the base called crash pad, to cushion the falls, forcing sudden and repetitive movements with degree of difficulty according to the Brazilian classification, which go, in increasing order, from v0 to v14. The indoor climbing is practiced in climbing gymnasiums with artificial walls, and can contemplate several other modalities of the sport, where the great differential is that all the movements can be planned and altered whenever necessary, in any degree of difficulty desired and not depending on weather conditions. ${ }^{1,3,4}$

In the 20th century, climbing began to win many Brazilian adepts, due to the emergence of the first certified guides and instructors ${ }^{1}$ and the multiplication of indoor climbing gyms, necessitating a comprehensive study of this population. ${ }^{5,6}$

Recently the practice was included as an Olympic sport at the Tokyo 2020 Olympic Games, which is likely to bring more popularity to the sport. ${ }^{7}$ With the increasing number of practitioners seeking personal and/ or competitive overcoming, the number of injuries has also increased, especially in the extremities of the upper limbs due to the high force required in the fingers, related to the time of practice, frequency of training, physical fitness, sports technique, degree of difficulty climbed, falls, sudden and repetitive efforts. ${ }^{8-12}$

The purpose of this study was to verify the prevalence of injuries in Brazilian climbers, as well as their association with sociodemographic characteristics and sports performance.

\section{MATERIALS AND METHODS}

An observational descriptive-analytic and cross-sectional study was conducted, applying a virtual questionnaire. The study sample consisted of 266 professional and recreational Brazilian climbers, of both sexes, with ages ranging from 18 to 45 years that have been climbing for more than 6 months.
The article was submitted and approved by the Research Ethics Committee (REC) of the Rio Grande do Norte League against Cancer, CAAE: 81623517.6.0000.5293. All the individuals in the present study accepted the Free and Informed Consent Term (FICT) and were studied respecting the norms of research involving human beings (Res. CNS 196/96) of the National Health Council.

The application of the virtual questionnaire ${ }^{11}$, through Google Forms, was conducted from March 16 to May 8, 2018, with Facebook, Instagram and whatsapp being used to disseminate it to climbers around the country, as well as the website of the Brazilian Mountain Hiking and Climbing Confederation (CBME), Blog de Escalada and Portal Marte. The main variables evaluated were age, sex, region of the country, BMI (body mass index), educational level, practice of other sports, professional or recreational category, climbing time, climbing course, stretching and warming up in climbing activities, degree of difficulty of the climb, frequency of practice, history of climbing injuries and characteristics of the injuries as to the sports modality, type, location, mechanism and treatment, as well as the climbing withdrawal time.

The statistical analysis of all the information collected was initially done in a descriptive way through absolute and relative frequencies (percentage). The inferential analysis used to confirm or refute evidence found in the descriptive analysis was performed with the Chi-Square test to compare the groups with and without history of injuries, according to sociodemographic and sports performance characteristics, considering the level of significance $p<0.05$.

The data was automatically tabulated in Google Sheets and then arranged in Microsoft Excel 2010 for proper storage of the information. Statistical analysis were performed in IBM SPSS Statistics 30.

\section{RESULTS}

The present study verified a prevalence of $71.8 \%$ of the history of injuries in Brazilian climbers ( $n=191)$. The characteristics of the injuries are described in Table 1, with prevalence of injuries in sports climbing being (22\%, $n=42)$, muscle-tendon type (50.8\%, n=97), upper limb (50,3\%; $n=96)$ and after abrupt movement (20.4\%, $n=39)$. Regarding the body location, the prevalence of injuries in the upper limb was on the fingers (Figure 1), the lower limb was on the ankle (Figure 2) and on other locations, on the back (Figure 3). The most common treatment by the Brazilian climbers studied was medical associated with the physiotherapeutic (34.5\%, n=66), detailed in Table 2. The maximum withdrawal time due to any injury was greater than 30 days (50.3\%; $\mathrm{n}=93$ ), as shown in Table 3.

The comparison of the sociodemographic characteristics of Brazilian climbers according to the injury was detailed in Table 4, with a prevalence of significant injury $(p<0.05)$ in the age range of 28 to 45 years, male, Southeast and Midwest regions, BMI classified as normal 
weight and overweight, higher education and practice or not of other sport besides climbing.

Regarding sports performance, the comparison according to the injury was detailed in Table 5, with a prevalence of significant injury ( $p$ $<0.05$ ) in the athlete and recreational categories, climbing time from four to more than six years, presence and absence of the basic climbing course, as well as performing warm-ups and stretches, rock climbing frequency greater than one time per month and more than one time per week in indoor climbing.

Regarding the degree of difficulty climbed, there was a significant prevalence $(p<0.05)$ of injury in sports climbing by those who climb from degree $7 \mathrm{a}$ to $11 \mathrm{c}$ and in bouldering from those who climb from degree of difficulty v0 to v11, as shown in Table 6.

Table 1. Characteristics of injuries of Brazilian climbers ( $n=191)$.

\begin{tabular}{|c|c|c|}
\hline Characteristics of injuries & $f$ & $\%$ \\
\hline \multicolumn{3}{|l|}{ Sports modalities } \\
\hline Sports Climbing & 42 & 22,0 \\
\hline Bouldering & 27 & 14,2 \\
\hline Traditional Climbing & 24 & 12,6 \\
\hline Indoor Climbing & 35 & 18,3 \\
\hline Sports + Bouldering & 24 & 12,6 \\
\hline Sports + Traditional & 4 & 2,1 \\
\hline Sports + Indoor & 16 & 8,4 \\
\hline Bouldering + Indoor & 12 & 6,3 \\
\hline Bouldering + Traditional & 1 & 0,5 \\
\hline Traditional + Indoor & 2 & 1,0 \\
\hline Sports + Bouldering + Indoor & 2 & 1,0 \\
\hline Sports + Bouldering + Traditional + Indoor & 2 & 1,0 \\
\hline Total & 191 & 100,0 \\
\hline \multicolumn{3}{|l|}{ Type of injury } \\
\hline Muscle-tendon & 97 & 50,8 \\
\hline Bone & 13 & 6,8 \\
\hline Joint & 28 & 14,6 \\
\hline Muscle-tendon + bone & 9 & 4,7 \\
\hline Muscle-tendon + joint & 40 & 21,0 \\
\hline Muscle-tendon + bone + joint & 4 & 2,1 \\
\hline Total & 191 & 100,0 \\
\hline \multicolumn{3}{|l|}{ Body location } \\
\hline Lower limb & 30 & 15,7 \\
\hline Upper limb & 96 & 50,3 \\
\hline Both limbs & 54 & 28,3 \\
\hline Another location & 11 & 5,7 \\
\hline Total & 191 & 100,0 \\
\hline \multicolumn{3}{|l|}{ Injury mechanism } \\
\hline Fall & 33 & 17,3 \\
\hline Repetitive motion & 38 & 20,0 \\
\hline Abrupt movement & 39 & 20,4 \\
\hline Fall + repetitive motion & 13 & 6,8 \\
\hline Fall + abrupt movement & 18 & 9,4 \\
\hline Repetitive motion + abrupt movement & 36 & 19,8 \\
\hline Fall + repetitive motion + abrupt movement & 14 & 7,3 \\
\hline Total & 191 & 100,0 \\
\hline
\end{tabular}

f: absolute frequency, \%: relative frequency.

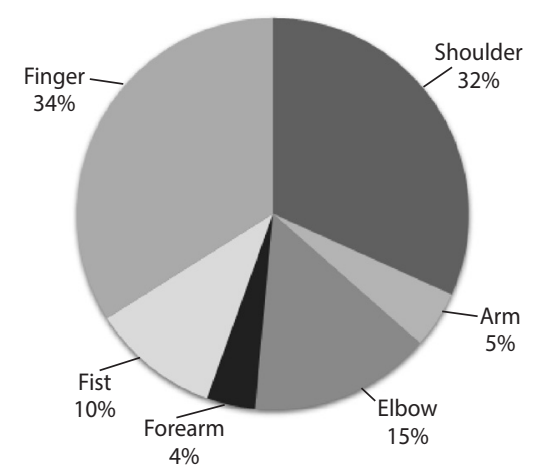

Figure 1. Body location affected in the upper limb $(n=150)$.

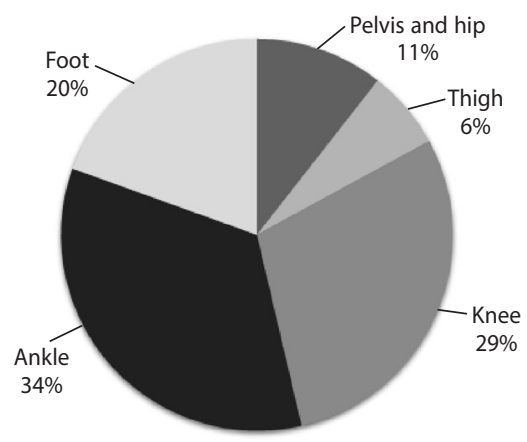

Figure 2. Body location affected in the lower limb ( $n=84)$.

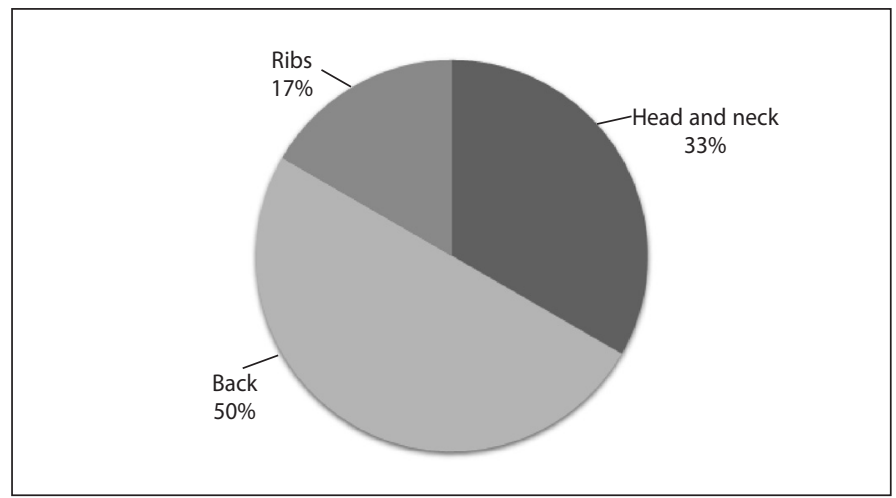

Figure 3. Other locations affected by injuries $(n=11)$.

Table 2. Characteristics of the treatment performed on Brazilian climbers after injuries $(n=191)$.

\begin{tabular}{c|c|c}
\hline Treatment & f & $\%$ \\
\hline Continued to climb & 12 & 6,4 \\
\hline Rest & 15 & 7,8 \\
\hline Medical & 32 & 16,8 \\
\hline Physiotherapeutic & 27 & 14,1 \\
\hline On their own & 39 & 20,4 \\
\hline Medical + physiotherapeutic & 66 & 34,5 \\
\hline Total & 191 & 100,0 \\
\hline
\end{tabular}

f: absolute frequency, \%: relative frequency.

Table 3. Ratio of maximum training withdrawal time, according to the International Registry of Injury Severity Scale, due to climbing injury ( $n=191)$.

\begin{tabular}{c|c|c|c}
\hline Variables & Withdrawal time & $\mathbf{f}$ & $\%$ \\
\hline Light & None & 8 & 4,1 \\
\hline Light to moderate & 1 to 15 days & 41 & 21,5 \\
\hline Moderate to severe & 16 to 30 days & 46 & 24,1 \\
\hline Severe & More than 30 days & 96 & 50,3 \\
\hline Total & & 191 & 100,0 \\
\hline
\end{tabular}


Table 4. Comparison of sociodemographic characteristics of Brazilian climbers due to injury $(n=266)$.

\begin{tabular}{|c|c|c|c|c|c|c|c|}
\hline \multirow{3}{*}{ Characteristics } & \multicolumn{4}{|c|}{ History of injuries } & \multirow{3}{*}{$x^{2}$} & \multirow{3}{*}{ df } & \multirow{3}{*}{$p$-value } \\
\hline & \multicolumn{2}{|c|}{ Yes $(n=191)$} & \multicolumn{2}{|c|}{ No $(n=75)$} & & & \\
\hline & $f$ & $\%$ & f & $\%$ & & & \\
\hline \multicolumn{8}{|l|}{ Age (years) } \\
\hline 18 to 27 & 43 & 61,4 & 27 & 38,6 & 3,657 & 1 & 0,056 \\
\hline 28 to 36 & 93 & 76,2 & 29 & 23,8 & 33,574 & 1 & $<0,001^{*}$ \\
\hline 37 to 45 & 55 & 74,3 & 19 & 25,7 & 17,514 & 1 & $<0,001^{*}$ \\
\hline \multicolumn{8}{|l|}{ Sex } \\
\hline Female & 44 & 58,7 & 31 & 43,1 & 2,553 & 1 & 0,133 \\
\hline Male & 147 & 77,0 & 44 & 23,0 & 55,545 & 1 & $<0,001^{*}$ \\
\hline \multicolumn{8}{|l|}{ Region } \\
\hline Northeast & 41 & 56,2 & 32 & 43,8 & 1,110 & 1 & 0,292 \\
\hline South & 22 & 64,7 & 12 & 35,3 & 2,941 & 1 & 0,086 \\
\hline Southeast & 110 & 79,7 & 28 & 20,3 & 48,725 & 1 & $<0,001^{*}$ \\
\hline Midwest & 18 & 85,7 & 3 & 14,3 & 10,714 & 1 & $0,001^{*}$ \\
\hline \multicolumn{8}{|l|}{ BMI classification } \\
\hline Underweight & 4 & 80,0 & 1 & 20,0 & 1,800 & 1 & 0,180 \\
\hline Normal weight & 151 & 71,2 & 61 & 28,8 & 38,208 & 1 & $<0,001^{*}$ \\
\hline Overweight & 34 & 73,9 & 12 & 26,1 & 10,522 & 1 & $0,001^{*}$ \\
\hline Obese Class I & 2 & 66,7 & 1 & 33,3 & 0,333 & 1 & 0,564 \\
\hline \multicolumn{8}{|l|}{ Educational level } \\
\hline Higher education & 174 & 73,4 & 63 & 26,6 & 51,987 & 1 & $<0,001^{*}$ \\
\hline High school & 16 & 60,0 & 9 & 40,0 & 1,000 & 1 & 0,317 \\
\hline Middle school & 2 & 50,0 & 2 & 50,0 & 0,000 & 1 & 1,000 \\
\hline \multicolumn{8}{|c|}{ Practice of other sports } \\
\hline Yes & 162 & 70,7 & 67 & 29,3 & 39,410 & 1 & $<0,001^{*}$ \\
\hline No & 29 & 78,4 & 8 & 21,6 & 11,919 & 1 & $0,001^{*}$ \\
\hline
\end{tabular}

f: absolute frequency, \%: relative frequency, $X^{2}$ : calculated chi-square value, $\mathrm{df}$ : degrees of freedom, ${ }^{*}$ significant difference for $\mathrm{p}<0,05$.

\section{DISCUSSION}

Due to the increase in popularity in Brazil, and a high rate of injuries seen in other countries, 8,9 mainly associated with biomechanics and strength required ${ }^{10}$, this study sought to analyze the prevalence of injuries in Brazilian climbers and associated factors. From the results obtained, it can be observed that the prevalence of injuries reached a margin of $71.8 \%$ of the individuals, corroborating with other studies such as the one performed with 369 British climbers, characterizing the prevalence of $81 \%$ of injuries in individuals. ${ }^{13}$

In this study, a prevalence of injuries in sports climbing was found, being a modality designed to have a greater safety, allowing the climber to risk more. ${ }^{1,3}$ In the search for climbing pathways with higher degrees of difficulty, climbers force sudden and repetitive movements, often leading to muscle fatigue and causing major impacts on the joints, as seen in this study, the significant prevalence $(p<0.05)$ of injuries in higher degrees of difficulty in sports climbing. Although sports climbing was prevalent in the injuries, the prevalence of bouldering injury was significant $(p<0.05)$ in all degrees of difficulty evaluated, not only the highest, since this modality is characterized by movements of explosion.
Table 5. Comparison of sports performance of Brazilian climbers due to injury $(n=266)$.

\begin{tabular}{|c|c|c|c|c|c|c|c|}
\hline \multirow{3}{*}{ Characteristics } & \multicolumn{4}{|c|}{ History of injuries } & \multirow{3}{*}{$X^{2}$} & \multirow{3}{*}{ df } & \multirow{3}{*}{$p$-value } \\
\hline & \multicolumn{2}{|c|}{ YES $(n=191)$} & \multicolumn{2}{|c|}{ NO $(n=75)$} & & & \\
\hline & f & $\%$ & $\mathbf{F}$ & $\%$ & & & \\
\hline \multicolumn{8}{|l|}{ Category } \\
\hline Professional & 41 & 85,4 & 7 & 14,6 & 24,083 & 1 & $<0,001^{*}$ \\
\hline Recreational & 150 & 68,8 & 68 & 31,2 & 30,844 & 1 & $<0,001^{*}$ \\
\hline \multicolumn{8}{|l|}{ Climbing time } \\
\hline 0,5 to 0,9 years & 6 & 40,0 & 9 & 60,0 & 0,600 & 1 & 0,439 \\
\hline 1 to 3 years & 54 & 65,1 & 29 & 34,9 & 7,530 & 1 & $0,006^{*}$ \\
\hline 4 to 6 years & 40 & 67,8 & 19 & 32,0 & 7,475 & 1 & $0,006^{*}$ \\
\hline More than 6 years & 91 & 83,5 & 18 & 16,5 & 48,890 & 1 & $<0,001^{*}$ \\
\hline \multicolumn{8}{|l|}{ Climbing course } \\
\hline Yes & 91 & 77,1 & 27 & 22,9 & 34,712 & 1 & $<0,001^{*}$ \\
\hline No & 100 & 67,6 & 48 & 32,4 & 18,770 & 1 & $<0,001^{*}$ \\
\hline \multicolumn{8}{|c|}{ Warming up / Stretching } \\
\hline Does & 45 & 70,3 & 19 & 29,7 & 10,563 & 1 & $0,001^{*}$ \\
\hline Does not & 146 & 72,3 & 56 & 27,7 & 40,099 & 1 & $<0,001^{*}$ \\
\hline \multicolumn{8}{|c|}{ Rock climbing frequency } \\
\hline Doesn't practice & 4 & 80,0 & 1 & 20,0 & 1,800 & 1 & 0,180 \\
\hline$<1 \times$ per month & 17 & 63,0 & 10 & 37,0 & 1,815 & 1 & 0,178 \\
\hline $1 \times$ per month & 20 & 71,4 & 8 & 28,6 & 5,143 & 1 & $0,023^{*}$ \\
\hline 2 to $4 x$ per month & 76 & 69,7 & 33 & 30,3 & 16,963 & 1 & $<0,001^{*}$ \\
\hline$>4 x$ per month & 74 & 76,3 & 23 & 23,7 & 26,814 & 1 & $<0,001^{*}$ \\
\hline \multicolumn{8}{|c|}{ Indoor climbing frequency } \\
\hline Doesn't practice & 32 & 56,1 & 25 & 43,9 & 0,860 & 1 & 0,354 \\
\hline$<1 \times$ per week & 33 & 61,1 & 21 & 38,9 & 2,667 & 1 & 0,102 \\
\hline 1x per week & 27 & 79,4 & 7 & 20,6 & 11,765 & 1 & $0,001^{*}$ \\
\hline 2 to $4 x$ per week & 89 & 80,2 & 22 & 19,8 & 40,441 & 1 & $<0,001^{*}$ \\
\hline$>4 x$ per week & 10 & 100,0 & 0 & 0,0 & - & - & - \\
\hline
\end{tabular}

f: absolute frequency, \%: relative frequency, $x^{2}$. calculated chi-square value, $d f$. degrees of freedom, * significant difference for $p<0,05,-:$ test not applicable.

Table 6. Comparison of the degree of difficulty climbed by Brazilians due to injury ( $n=266)$.

\begin{tabular}{|c|c|c|c|c|c|c|c|}
\hline \multirow{3}{*}{ Degree of difficulty } & \multicolumn{4}{|c|}{ History of injuries } & \multirow{3}{*}{$x^{2}$} & \multirow{3}{*}{ df } & \multirow{3}{*}{$\mathrm{p}$-value } \\
\hline & \multicolumn{2}{|c|}{ Yes $(n=191)$} & \multicolumn{2}{|c|}{ No $(n=75)$} & & & \\
\hline & $f$ & $\%$ & $f$ & $\%$ & & & \\
\hline \multicolumn{8}{|l|}{ Sports climbing } \\
\hline $1-3$ sup & 3 & 42,9 & 4 & 57,1 & 0,143 & 1 & 0,707 \\
\hline $4-6$ sup & 43 & 55,8 & 34 & 44,2 & 1,052 & 1 & 0,305 \\
\hline $7 a-9 a$ & 114 & 76,5 & 35 & 23,5 & 41,866 & 1 & $<0,001^{*}$ \\
\hline $9 b-11 c$ & 31 & 93,9 & 2 & 6,1 & 25,485 & 1 & $<0,001^{*}$ \\
\hline \multicolumn{8}{|l|}{ Bouldering } \\
\hline$v 0-v 3$ & 82 & 62,6 & 49 & 37,4 & 8,313 & 1 & $0,004^{*}$ \\
\hline $\mathrm{v} 4-\mathrm{v} 7$ & 66 & 75,0 & 22 & 25,0 & 22,000 & 1 & $<0,001^{*}$ \\
\hline $\mathrm{v} 8-\mathrm{v} 11$ & 39 & 95,1 & 2 & 4,9 & 33,390 & 1 & $<0,001^{*}$ \\
\hline v12 - v15 & 4 & 66,7 & 2 & 33,3 & 0,667 & 1 & 0,414 \\
\hline
\end{tabular}

f: absolute frequency, \%: relative frequency, $X^{2}$ : calculated chi-square value, df: degrees of freedom, significant difference for $\mathrm{p}<0,05$. 
In a study with 699 injured climbers from 2002 to 2006, a greater frequency of muscle, ligament and bone injuries, was observed with greater frequency in the extremities of the upper $\operatorname{limb}{ }^{14}$ being similar to this study.

The hands are used as climbing tools, with much of the weight of the climber placed on the fingers and distributed through the wrist, elbow and shoulder, with those being the most injured body locations in the practitioners of the sport, with emphasis on the pulley, since in some situations it is required the two finger or even the single finger catch supporting the whole body weight. ${ }^{10}$ Nelson, Rayan and Judd performed a study with 357 climbers with a history of injuries, where $41 \%$ were located on the fingers, $20 \%$ on the shoulder and arm, and $19 \%$ on the forearm and elbow. ${ }^{15}$

In the lower limb the ankle was the most affected body location among the climbers in this study, followed by the knee and foot. Schoffl and Kupper ${ }^{16}$ emphasize the need for a tighter climbing shoe for a better fit of the needs and demands of the sport in high performance, making the footstep more precise, especially in the routes with more advanced degrees of difficulty, being a characteristic of the sports and bouldering modality. By contrast, in traditional climbing and for recreational climbers is indicated a shoe that is good to support the feet in the grabs, but that is comfortable and does not hurt, reducing the risk of pains and injuries. Authors mention that tight climbing shoes can alter the structure of the toes, forcing the hallux laterally. ${ }^{17}$

The most sought treatment by the subjects of this study was the medical and physiotherapeutic. Jones, Asghar and Lewellyn observed in their study that physiotherapeutic treatment was the most sought by climbers, followed by informal consultation with other climbers and then physicians, suggesting that the greater search for physiotherapeutic treatment may be associated with the higher chronic skeletal-muscle injuries, found in climbers, requiring a more durable, non-surgical or medicated treatment. ${ }^{18}$

This research also looked for the sociodemographic factors that may be associated with the prevalence of injuries, finding a greater significant frequency of presence of injury in climbers from 28 to 45 years and male. Neuhof et al. ${ }^{19}$ conducted a study in 14 countries ( $n=1962)$, where 1583 (80.7\%) climbers with lesions were found to be male, with a mean age of $32.8 \pm 9.4$ years, ranging from 13 to 60 years, corroborating this study, even though the age group was more comprehensive. This study ${ }^{19}$ also showed a significant prevalence ( $p<0.05$ ) of injuries associated with longer climbing time, higher difficulty level and high training frequency, being similar to this study, showing that even the most experienced climbers have a higher tendency to be injured, being climbing a challenging sport, where the practitioner will always have some degree of difficulty ahead to be overcome.

The Body Mass Index of the climbers was predominantly healthy (79.7\%, $\mathrm{n}=212)$. Garcez and Almeida ${ }^{20}$ observed in their study that practitioners of sports perfomed in the nature have a tendency to take greater care of their body, health and well-being, corroborating with this study. Nevertheless, there was a significant prevalence $(p<0.05)$ of injuries in individuals characterized as healthy and overweight in this study, needing to evaluate the individuals associating other factors and not only this alone, considering that other characteristics may also influence the history of injuries and quality of life.
Higher education was the most frequent level of schooling in this study (89.1\%; n=237), with a higher prevalence of injuries. Pimentel and Saito ${ }^{21}$ observed in their study $(n=207)$ performed with individuals from 10 to 78 years, that schooling and professional stability increase the chances of an individual practicing adventure activities, which corroborates with the findings of this article, given that with these conditions the individual has greater financial ease and independence to acquire climbing equipment, travel to climb and maintain a more constant training pace, allowing even to develop more in the sport.

Although most climbers practice the sport only for leisure, there is the informal requirement of the basic climbing course for everyone, preferably as soon as the interest for practice starts, as it is a life-threatening sport. In Brazil, the course is offered by compulsorily certified instructors, who must meet a series of requirements until they reach the degree. ${ }^{22}$ Nevertheless, in this study $55.6 \%$ of the climbers did not have the certificate of the course, and although there was a prevalence of injury both in the group with climbing course and in the group without the course, as well as the prevalence in the group which performs and does not perform stretching and warm-ups before climbing, it is suggested a greater dissemination and internal requirement of the associations for the practice, and also the inclusion of a module made by physical educators and physiotherapists focused on the physical conditioning and the corporal awareness of these practitioners, seeking the reduction of the risk of injuries, since the courses are focused solely on the safety and technique of the sport.

Climbing in Brazil, organized by the Brazilian Mountain Hiking and Climbing Confederation (CBME), Brazilian Association of Sports Climbing (ABEE) and other state associations, has great potential for the practice of the sport, where during the course of the year are hosted events that provide integration with the local community and encourage people from all over the world to attend these climbing poles. In this study, the highest number of climbers observed was in the Southeast (51.9\%, $n=138$ ) and the prevalence of injuries was significant $(p<0.05)$ for the Southeast and Midwest groups. Since this study was a pioneer in Brazil, new studies are needed that seek methods to contemplate more broadly all the regions, including the North, which was not represented in this study for lack of answers. ${ }^{23-25}$

\section{CONCLUSION}

The fact that more than half of the climbers presented some type of injury, draws attention to programs aimed at health promotion, with the purpose of reducing this prevalence, due to the significant increase in the number of participants and sporting events. Risk reduction measures and guidelines should be the focus of health professionals in order to promote better quality of life for the climbing practitioners.

The limitations of the study include age, recruitment, sample for convenience and cross-sectional design. However, the results of the present study may encourage the professionals involved in the training and application of the basic courses to review the models of periodization and protocols applied. There is also a need for prospective studies regarding the possible associations between these variables.

All authors declare no potential conflict of interest related to this article

AUTHORS' CONTRIBUTIONS: Each author made significant individual contributions to this manuscript. AFCF (0000-0002-7306-7287)*: study design, data analysis, study interpretation, writing, critical review of the article, final approval of the article, responsibility for all aspects of the study. LFCB (0000-0003-0875-9719)*: study design, critical review of the article and intellectual content, final approval of the article, responsibility for all aspects of the study. KMPS (0000-0001-9542-353X)*: study design, critical review of the article and intellectual content, final approval of the article, responsibility for all aspects of the study. GMR (0000-0001-8914-2950): data analysis, study interpretation, responsibility for all aspects of the study. All authors approved the final version of the manuscript. *ORCID (Open Researcher and Contributor ID). 


\section{REFERENCES}

1. Daflon F, Daflon C. Escale melhor e com mais segurança. Companhia da Escalada. $4^{\text {nd }}$ ed. Companhia de Escalada; 2016.

2. Giles D, Draper N, Gilliver P, Taylor N, Mitchell J, Birch L, et al. Current understanding in climbing psychophysiology research. Sports Technol. 2014;7(3-4):108-19.

3. Bertuzzi R, Lima-Silva AE. Principais características dos estilos de escalada em rocha e indoor. Rev Acta Bras Mov Humano. 2013;3(3):31-46.

4. Miitelstaedt R. Indoor climbing walls: the sport of the nineties. J Phys Educ Recr Dance. 1997;68(9):26-9.

5. Hartoscok LA, Feagin JA Jr, Oglvie BC. Climbing and the Older Athete. Clin Sports Med. 1991;10(2):257-67.

6. Hochholzer T, Schoffl V. One Move Too Many. $2^{\text {nd }}$ ed. Ebenhausen: Lochner Verlag; 2006.

7. Lutter C, Elsheikh Y, Schoffl I, Schoffl V. Sport climbing: medical considerations for this new Olympic discipline. Br J Sports Med. 2017;51(1):2-3.

8. Paige TE, Fiore DC, Houston, JD. Injury in traditional and sport rock climbing. Wilderness Environ Med. 1998;9(1):2-7.

9. Gerdes EM, Hafner JW, Aldag JC. Injury Patterns and Safety Practices of Rock Climbers. J Trauma. 2006;61(6):1517-25

10. Pozzi A, Pivato A, Pegolli L. Hand injury in rock climbing: literature review. J Hand Surg Asian Pac Vol. 2016;21(1):13-7.

11. Wright DM, Royle TJ, Marshall T. Indoor Rock Rlimbing:Who Gets Injured? Br J Sports Med. 2001;35(3):181-5.

12. Morrison AB, Schoffl V. Physiological responses to rock climbing in young climbers. Br J Sports Med. 2007;41(12):852-61.

13. Jones G, Woodard C, Sharples P, Johnson M. Self-reported injury mechanisms in climbers. Br J Sports Med. 2017;51(4):336-7.

14. Schöffl V, Dominik P, Küpper T, Schöffl I. Injury trends in rock climbers: evaluation of a case series of
911 injuries between 2009 and 2012. Wilderness Environ Med. 2015;26(1):62-7.

15. Nelson CE, Rayan GM, Judd DI, Ding K, Stoner JA. Survey of hand and upper extremity injuries among rock climbers. Hand (N Y). 2017;12(4):389-94.

16. Schoffl V, Kupper T. Feet injuries in rock climbers. World J Orthop. 2013;4(4):218-28.

17. Van der Putten EP, Snijder CJ. Shoe design for prevention of injuries in sport climbing. Appl Ergon. 2001;32:379-87.

18. Jones G, Asghar A, Llewellyn DJ. The epidemiology of rock-climbing injuries. Br J Sports Med. 2008;42(9):773-8

19. Neuhof A, Henning FF, Schöffl L, Schöffl V. Injury risk evaluation in sport climbing. Int J Sports Med. 2011;32(10):790-800.

20. Garcez B, Almeida FQ. Montanhismo no Espírito Santo: perfis da associação capixaba de escalada (ACE). Rev Corpoconsciência. 2015;19(3):22-37.

21. Pimentel GG, Saito CF. Caracterização da demanda potencial por atividades de aventura. Motriz. 2010;16(1):152-61.

22. Bugim P. Regulamento do Programa de Certificação de Cursos Básicos de Esportes de Montanha. Federação de Esportes de Montanha do Estado do Rio de Janeiro [internet]. 2017. [acesso em 2018 jun 01]. Disponível em: http//www.femerj.org/biblioteca/cursos-basicos.

23. Santos EM. O Encontro de Escaladores do Nordeste: História [internet]. 2017. [acesso em 2018 jun 01]. Disponível em: http://www.eene.com.br/historia.php\&gt

24. ABEE. Associação Brasileira de Escalada Esportiva [internet]. 2017. [acesso em 2018 jun 01]. Disponível em: http://www.abee.net.br

25. CBME. Confederação Brasileira de Montanhismo e Escalada [internet]. 2017. [acesso em 2018 jun 01]. Disponível em: http://www.cbme.org.br/novo/ 